Jurnal Esensi Hukum

\title{
UPAYA PENANGGULANGAN TINDAK PIDANA KORUPSI PADA MASA PANDEMI COVID 19
}

\author{
Yonta do Parapat ${ }^{1}$, Katina Pakpahan ${ }^{2}$, Satria Jaya Bukit ${ }^{3}$, \\ Afri Jansen Tarigan ${ }^{4}$ \\ ${ }^{1}$ Fakultas Hukum Universitas Prima Indonesia, Medan \\ E-maiL: parapat284@gmail.com \\ ${ }^{2}$ Fakultas Hukum Universitas Prima Indonesia, Medan \\ E-mail: kartinapakpahan@unprimdn.ac.id \\ ${ }^{3}$ Fakultas Hukum Universitas Prima Indonesia, Medan \\ ,4Fakultas Hukum Universitas Prima Indonesia, Medan
}

\begin{abstract}
The covid-19 Pandemic must be tackled quickly, both government and society. The covid-19 Pandemic changed the lives of all Indonesians. In disaster management, it is the responsibility of the government to provide management to provide protection for the community from the threat of natural disasters and to ensure the implementation of planned, integrated, coordinated and comprehensive disaster management. This study aims to determine the regulation of criminal acts of corruption that were carried out during the Covid-19 Pandemic, the penalties that will be given to perpetrators of corruption during the Covid-19 Pandemic and how to tackle corruption crimes during the Covid-19 Pandemic. The method used in this research is the Normative Juridical Method. Legal efforts in eradicating criminal acts of corruption carried out during the Covid-19 Pandemic carried out two strategies, namely preventive and repensive efforts. The community must fully support all Government policies.
\end{abstract}

Keywords: Covid-19, Corruption, Prevention

\begin{abstract}
Abstrak
Pandemi covid-19 harus ditanggulangi secara cepat, baik pemerintah ataupun masyarakat. Pandemi covid-19 mengubah kehidupan seluruh masyarakat Indonesia. Dalam penanganan bencana adalah tanggung jawab dari pemerintah memberikan penanganan terhadap memberi perlindungan masyarakat dari ancaman bencana alam dan menjamin terselenggarakannya penanggulangan bencana yang terencana, terpadu, terkoordinasi dan menyeluruh. Penelitian ini bertujuan untuk mengetahui pengaturan tindak pidana korupsi yang dilakukan pada saat Pandemi Covid-19, hukuman yang akan diberikan pada pelaku pidana korupsi pada masa Pandemi Covid-19 dan upaya penanggulangan tindak pidana korupsi pada masa Pandemi covid-19. Adapun metode yang digunakan dalam penelitian ini adalah Metode Yuridis Normatif. Upaya hukum dalam memberantas tindak pidana korupsi yang dilakukan pada masa Pandemi covid 19 melakukan dua strategi yaitu upaya preventif dan reprensif. Masyarakat harus mendukung penuh seluruh kebijakan Pemerintah.
\end{abstract}

Kata Kunci: Covid-19, Korupsi, Penanggulangan

\section{Pendahuluan}

\subsection{Latar Belakang}


Korupsi dari bahasa latin corruption, dari kata kerja corrumpere yang berarti busuk, rusak,menggoyahkan, memutar balik, menyogok. Korupsi adalah perilaku pejabat publik, baik politis maupun pegawai negeri, yang secara tidak wajar dan tidak legal memperkaya diri atau memperkaya mereka yang dekat dengannya, dengan menyalahgunakan kepercayaan publik yang dikuasakan kepada mereka untuk mendapatkan keuntungan sepihak. Secara harfiah kata korupsi menunjuk pada perbuatan yang rusak, busuk, tidak jujur yang dikaitkan dengan keuangan.

Pandemi virus covid-19 atau yang sering disebut corona saat ini semakin menjangkiti perekonomian indonesia. Dampak ekonomi akibat virus semula hanya menggerus sisi dari ekternal perekonomian Indonesia. Komisi Pemberantasan Korupsi (KPK) menerbitkan dua surat edaran yaitu SE Nomor 8 Tahun 2020 tentang Penggunaan Anggaran Pelaksanaan Pengadaan Barang/Jasa dalam rangka percepatan pelaksanaan pengadaan barang dan jasa dalam rangka percepatan penanganan covid-19 terkait dengan pencegahan tindak pidana korupsi. KPK mendorong tiga poin utama dalam pencegahan korupsi pada pengadaan barang $\backslash$ jasa atau sering disebut PBJ dalam rangka percepatan penangan Covid-19 pada tingkat pusat dan daerah. Pelaksanaan pengadaan barang dan jasa tetap memperhatikan peraturan perundang-undangan yang berlaku termasuk aturan secara khusus yang dikeluarkan LKPP. Komisi Pemberantas Korupsi sangat mendorong keterlibatan Aparat Pengawasan Intern Pemerintah (APIP) atau (Badan Pengawasan Keuangan dan Pembangunan) BPKP dalam melakukan pengawalan dan pendampingan terkait proses pelaksanaan pengadaan barang dan jasa serta berkonsultasi dengan LKPP. ${ }^{1}$

Prinsip pengadaan barang dan jasa pada kondisi darurat ini sangat efektif akuntabel maupun transparan dengan berpegang teguh pada konsep harga yang terbaik yang dicantumkan didalam Pasal 4 Peraturan Presiden Nomor 16 Tahun 2018 tentang Pengadaan Barang dan Jasa oleh Pemerintah. Tujuan pengadaan barang dan jasa pada perpres tersebut untuk menghasilkan barang/jasa yang tepat dari setiap uang yang dibelanjakan dan hal ini bisa diukur dari aspek kualitas, jumah, lokasi dan penyediaannya.

Tindak pidana korupsi salah satu penyebab sistem perekonomian bangsa menurun sangat pesat, karena korupsi di Indonesia terjadi secara meluas sehingga merugikan perekonomian negara atau kondisi keuangan negara. Perlu penanggulangan tindak pidana korupsi dengan cara yang sangat luar biasa dan perlu menciptakan cara-cara yang khusus. Korupsi sebagai perbuatan yang dilakukan dengan maksud untuk memberikan suatu keuntungan yang tidak resmi dengan hak-hak dari pihak lain secara salah, menggunakan jabatannya atau karakternya untuk mendapatkan suatu keuntungan untuk dirinya sendiri atau orang lain, berlawanan dengan kewajibannya dan hak-hak dari pihak-pihak lain. ${ }^{2}$

Korupsi merupakan penyogokan, penyuapan, penggelapan, perbuatan yang buruk atau sering disebut suka menerima uang sogok, penyalahgunaan jabatan/wewenang untuk kepentingan diri sendiri, melakukan suatu tindakan pidana dengan maksud memperkaya diri sendiri secara langsung maupun tidak

${ }^{1}$ Surat Edaran Komisi Pemberantasan Korupsi Republik Indonesia Nomor 8 Tahun 2020

${ }^{2}$ Syamsuddin,A. (2011). Tindak Pidana Khusus. Jakarta: Sinar Grafika, hlm.137. 
langsung dimana perbuatan itu merugikan keuangan negara dan perekonomian dalam negara. ${ }^{3}$ Korupsi adalah suatu perbuatan anti sosial yang sering dikenal sebagai belahan dunia, namun beberapa orang mengartikan bahwa korupsi bukan suatu bentuk kejahatan yang baru dan kejahatan ini hanya berkembang di indonesia ini.

Dengan adanya predikat bahwa tindak pidana korupsi merupakan kejahatan luar biasa (Extraordinary Crime), maka harus ada peraturan atau undang-undang khusus yang mengatur mengenai tindak pidana korupsi. Tindak Pidana Korupsi diatur lebih khusus pada Undang-Undang No. 20 tahun 2001 tentang perubahan atas Undang-Undang No. 31 tahun 1999 tentang Pemberantasan Tindak Pidana Korupsi. Adanya Undang-Undang No. 20 tahun 2001, maka dalam pemberantasan tindak pidana korupsi digunakan asas hukum yaitu "lex specialis derogat legi generali", yaitu asas penafsiran hukum yang menyatakan bahwa hukum yang bersifat khusus (lex specialis) mengesampingkan hukum yang bersifat umum (lex generalis). ${ }^{4}$

Upaya yang dapat dilakukan adalah dengan membentuk suatu peradilan khusus untuk Tindak Pidana Korupsi sebagaimana disebutkan dalam UndangUndang No.46 Tahun 2009 pasal 2 menyebutkan bahwa Pengadilan Tindak Pidana Korupsi merupakan pengadilan khusus yang berada di lingkungan Peradilan Umum. Dalam hal ini Pengadilan Tindak Pidana Korupsi merupakan satu-satunya pengadilan yang berwenang memeriksa, mengadili, dan memutus perkara tindak pidana korupsi. ${ }^{5}$ Peraktik-praktik mafia paling sering menggerogoti sendi-sendi kriminal atau sistem pengadilan pidana di Indonesia ini dimulai sejak proses penyelidikan, penuntutan, pemutusan eksekusi dan pemasyarakat. ${ }^{6}$

Saat ini banyak masyarakat bersikap sinis terhadap tiap usaha yang dilakukan untuk memberantas kasus korupsi yang dilakukan pemerintah, namun usaha yang dilakukan pemerintah dalam memberantas korupsi gagal. Hal ini menunjukkan bahwa masyarakat menjadi rendah yang selalu menjadi korban dari ketidakadilan dalam melakukan suatu tindakan hukum terhadap setiap kasus korupsi. Masyarakat sangat berharap agar pelaku tindak pidana korupsi mendapat hukuman yang setimpal. Strategi pemberian hukuman yang berat diperlukan dalam korupsi karena hal ini merupakan bukan suatu bentuk penyimpangan perilaku, karena korupsi merupakan suatu tindakan kejahatan yang direncanakan yang diperhitungkan untung dan rugi oleh suatu pelanggar hukum yang memiliki status terhormat.

Komisi Pemberantasan Korupsi (KPK) telah memetakan titik rawan terjadinya korupsi ditengah Pandemi covid-19. KPK membuat titik rawan potensi tindak pidana korupsi ditengah Pandemi ini, keempat titik itu seperti sektor pengadaan barang dan jasa, titik sumbangan pihak ketiga, pengalokasian anggaran dari APBN

\footnotetext{
${ }^{3}$ Sholihin,F. dan Yulianingsih, W. (2015). Kamus Hukum Kontemporer. Surabaya: Sinar Grafika, hlm.109

${ }^{4}$ Wikipedia. Lex Specialis Derogat Legi Generali. Diakses di https://id.m.wikipedia.org pada tanggal 10 Mei 2020

${ }^{5}$ Undang-Undang Nomor 46 Tahun 2009 Tentang Pengadilan Tindak Pidana Korupsi

${ }^{6}$ Hartanti, E. (2009). Tindak pidana korupsi edisi kedua. Jakarta: Sinar Erlangga, hlm.12
} 
maupun APBD baik itu alokasi sumber belanja maupun program bantuan sosial dalam rangka social safety ${ }^{7}$

\subsection{Rumusan Masalah}

1. Bagaimana pengaturan tindak pidana korupsi yang dilakukan pada saat Pandemi Covid-19?

2. Bagaimana hukuman yang akan diberikan pada pelaku pidana korupsi pada masa Pandemi Covid-19?

3. Bagaimana upaya penanggulangan tindak pidana korupsi pada masa Pandemi covid-19

\section{Metode Penelitian}

Metode penelitian ini menggunakan hukum normatif, metode penelitian menggunakan berbagai data sekunder seperti peraturan perundang-undangan, putusan pengadilan, teori hukum dan pendapat para sarjana. ${ }^{8}$ Menggunakan pendekatan perundang-undangan dan teknik analisis data yang digunakan dalam penelitian adalah Analisis Kualitatif.

\section{Hasil dan Pembahasan}

\subsection{Pengaturan Tindak Pidana Korupsi yang Dilakukan Pada Saat Pandemi Covid-19}

Indonesia merupakan negara yang rawan bencana alam, dimana bencana ini harus dihadapi dalam waktu-waktu tertentu, maka diperlukan penanggulangan yang harus ditangani secara komperensif. Pandemi covid-19 di Indonesia hingga saat ini belum menemukan bagaimana cara penanggulangannya hingga saat ini jumlah yang terjangkit semakin bertambah. Indonesia masih berjuang menangani Pandemi. Upaya yang dapat dilakukan pemerintah dalam mengatasi penyebaran covid-19 bahwa di terbitkan Peraturan Pemerintah Pengganti Undang-Undang No 1 tahun 2020 tentang Kebijakan Keuangan Negara dan Stabilitas Sistem Keuangan pada Pasal 4 memberikan penanganan Pandemi Covid-19 bahwa kebijakan keuangan negara yang termasuk kebijakan dalam perpajakan, kebijakan dalam bidang keuangan daerah, dan kebijakan pembiayaan. ${ }^{9}$ Penanganan bencana adalah suatu tanggung jawab dari pemerintah karena tujuan utama dalam memberikan penanganan terhadap perlindungan masyarakat dari ancaman bencana alam dan menjamin terselenggarakannya penanggulangan bencana yang terencana, terpadu, terkoordinasi dan menyeluruh. Penanggulangan bencana merupakan kegiatan atau upaya yang dilaksanakan dalam rangka pencegahan, litigasi, tanggap darurat dan pemulihan berkaitan dengan bencana yang dilakukan sebelum dan setelah bencana ${ }^{10}$

${ }^{7}$ Mubarok, F. KPK Petakan Titik Rawan Praktik Korupsi di Tengah Pandemi Covid-19. diakses di https://www.alinea.id/nasional/kpk-petakan-rawan-praktik-korupsi-di-tengahPandemi-covid-19-b1ZLA9tQQ pada tanggal 12 juni 2020

${ }^{8}$ Waluyo,B. (1996). Penelitian Hukum Dalam Praktik. Jakarta: Sinar Grafika, hlm 13.

${ }^{9}$ Perppu No 1 Tahun 2020 Tentang Kebijakan Keuangan Negara dan Stabilitas Sistem Keuangan Untuk Memberikan Penanganan Pandemi Covid-19

10 Yayasan. (2007). Buku Panduan Umum Pennggulangan Bencana Berbasis Masyarakat. Bali, hlm. 35 
Sistem penanggulangan bencana di Indonesia menghasilkan rekomendasi kebijakan strategi dalam kegiatan penanggulangan bencana. Sistem penananggulangan bencana dikembangkan dengan baik ditingkat nasional maupun daerah. Ada kewenangan beberapa lembaga secara tidak langsung tidak berada dalam kewenangan atau tugas pokok dari BNPB dan jika terjadi bencana alam maka akan mengalami kesulitan dalam melakukan koordinasi serta menimbulkan kelambatan dalam melaksanakannya. Penyelenggara penanggulangan bencana bedasarkan Undang-Undang Nomor 24 Tahun 2007 mengakibatkan dampak yang relatif besar yaitu berupa korban beserta kerugian harta benda yang seharusnya dikurangi. Undang-undang penanggulangan bencana mengatur mengenai penyelenggaran penanggulangan bencana dari landasan nilai, kelembagaan sampai kewenangan. Meskipun penyelenggara penanggulangan bencana alam telah diatur dengan UndangUndang beserta pelaksanaanya. Undang-Undang penanggulangan bencana yang berguna untuk menyelenggarakan penanggulangan bencana yang dapay terkoordinasi secara baik.

Pasal 3 Keputusan Presiden Nomor 7 Tahun 2020 tentang gugus tugas percepatan penanganan corona virus disease 2019 (covid-19) menyatakan bahwa kesehatan dan untuk anggaran dana yang dikeluarkan pemerintah untuk penanganan covid-19 sampai ratusan triliun. Pada faktanya ketimpangan-ketimpangan banyak terjadi hanya saja belum terkuak ke publik. Presiden Joko Widodo mengatakan bahwasanya dana anggaran kesehatan Covid-19 sangat mengecewakan. Dana yang disalurkan sangat kecil yang oleh pemerintah kepada masyarakat.

Pasal 3 Keputusan Presiden Nomor 7 Tahun 2020 tentang gugus tugas percepatan penanganan corona virus disease 2019 (covid-19) ini sudah jelas disebutkan bahwa meningkatkan ketahanan nasional di bidang kesehatan sangat jelas tetapi realita fakta yang dilihat sangat jauh dari yang diharapkan. Berbicara tentang Covid-19 tidak cukup hanya berbicara kesehatan karena sektor perekonomian bangsa juga harus dipikirkan sertor pendidikan juga.

Pasal 3 Keputusan Presiden Nomor 7 Tahun 2020 cukup tepat tetapi pengawasan diperlukan terhadap berjalannya operasional penanganan covid-19, memperhatikan perjalananan anggaran dana yang disalurkaan untuk penanganan covid 19 demi meminimalisir ketimpangan-ketimpangan. Kita ketahui bersama imbas covid 19 mempengaruhi seluruh belahan dunia baik dalam kesehatan, pendidikan, ekonomi dan lain sebagainya. Jadi menurut penulis untuk mengeluarkan peraturan ataupun Undang-Undang mengenai covid-19 perlu pertimbangan yang matang.

Berbicara undang-undang pemberantasan korupsi sudah cukup jelas akan tetapi yang menjadi permasalahannya adalah konsekuensi hukum bagi para pelaku korupsi belum ada jaminan undang-undang, dan para pelaku penegak hukum yang bermasalah moral karena masalah korupsi tidak terlepas dari suap menyuap (realita) dan itu bukan rahasia umum lagi. Undang-undang pembuktian terbalik harus diberlakukan untuk menyikat tuntas pelaku korupsi, dan hukum yang digunakan harus menggunakan akal sehat bukan berlandaskan kertas bukti saja.

\subsection{Hukuman Yang Akan Diberikan Pada Pelaku Pidana Korupsi Pada Masa Pandemi Covid 19}


Komisi Pemberantasan Korupsi (KPK) akan memberikan hukuman yang lebih tegas bagi yang melakukan tindak pidana korupsi ditengah Pandemi corona covid-19. KPK telah bekerja sama dengan lembaga kebijakan pengadaan barang/jasa pemerintah. KPK menegaskan bahwa akan memberikan hukuman mati bagi yang melakukan tindak pidana korupsi khususnya yang terdapat di Pasal 2 bahwa dalam keadaan tertentu yang dimaksudkan sebagai pemberatan bagi pelaku tindak pidana tersebut yang dilakukan pada waktu negara dalam keadaan bahaya yang sesuai dengan undang-undang yang berlaku yang pada waktu terjadi bencana nasional atau pada waktu negara dalam keadaan krisis ekonomi. Pasal 27 ayat (1) tentang biaya yang telah dikeluarkan pemerintah untuk penanganan covid-19 ini bukan keuangan negara dan hal ini tanggung jawab pengelolaan keuangan negara yang terdapat di UndangUndang Nomor 17 Tahun 2003 tentang Keuangan Negara dan Undang-Undang Nomor 15 Tahun 2004 tentang Pemeriksaan dan Tanggung Jawab Keuangan Negara. ${ }^{11}$

Teori pemidanaan dalam sistem eropa kontinental adalah teori absolut, teori relatif, teori gabungan. Teori pemidanaan dikenal dengan sistem anglo saxon yaitu teori retribusi, teori penangkalan dan teori rehabilitasi. Teori absolut merupakan seorang dapat menerima pemidanaan karena seseorang melakukan tindak pidana, perbuatan pidana terletak ketika terjadinya kejahatan itu sendiri. Maka teori ini dianggap sebagai dasar hukum dan tujuannya adalah pikiran untuk pembalasan.

KUHP yang berlaku pada saat ini belum mengenal hal yang dinamakan pedoman pemidanaan, oleh karena itu, hakim dalam memutus suatu perkara diberi kebebasan memilih jenis pidana yang dikehendaki, sehubungan dengan sistem alternatif dalam pengancaman didalam undang-undang. Selanjutnya hakim juga dapat memilih berat ringannya pidana (strafmaat) yang akan dijatuhkan, sebab yang ditentukan oleh undang-undang hanya maksimum dan minimum pidana. Sehubungan dengan hal tersebut, maka yang sering menimbulkan masalah dalam praktik adalah mengenai kebebasan hakim dalam menentukan berat ringannya pidana yang diberikan. Hal ini disebutkan undang-undang hanya menentukan batas maksimum dan minimum pidananya saja, sebagai konsekuensi dari masalah tersebut, akan terjadi hal yang disebut dengan disparatas pidana yang merugikan negara dan perekonomian negara.

Penanganan bencana merupakan tanggung jawab dari pemerintah karena tujuan utama dalam memberikan penanganan adalah memberi perlindungan masyarakat dari ancaman bencana alam dan menjamin terselenggarakannya penanggulangan bencana yang terencana, terpadu, terkoordinasi dan menyeluruh. Penanggulangan bencana merupakan kegiatan atau upaya yang dilaksanakan dalam rangka pencegahan, mitigasi, tanggap darurat dan pemulihan. ${ }^{12}$

Upaya yang dilakukan oleh komisi pemberantasan korupsi adalah menerbitkan Surat Edaran Nomor 8 Tahun 2020 tentang penggunaan pelaksanaan pengadaan Barang/Jasa dalam rangka percepatan penanganan Covid-19 yang terkait dengan pencegahan tindak pidana korupsi. KPK mengidentifikasikan modus dan potensi korupsi bahwa persekongkolan dengan penyediaan barang, penyuapan, perbuatan curang, hingga terjadinya tindak pidana. Upaya pencegahan yang dilakukan KPK

${ }^{11}$ Undang-Undang Nomor 15 tahun 2004 tentang Pemeriksaan dan Tanggung Jawab Keuangan Negara

${ }^{12}$ Undang-Undang Nomor 24 Tahun 2007 Tentang Penanggulangan Bencana 
dalam pengadaan barang dan jasa didalam penanganan Covid-19 yang misalnya pengadaan APD, maka KPK melakukan monitoring dan membantu koordinasi Gugus Tugas percepatan Covid-19 ditingkat Nasional beserta daerah terkait pencegahan korupsi.

Tabel 1 Undang-Undang Nomor 31 Tahun 1999 Tentang Pemberantasan Tindak Pidana Korupsi

\begin{tabular}{|c|c|c|c|}
\hline No & PASAL & $\begin{array}{l}\text { UNSUR-UNSUR } \\
\text { TINDAK PIDANA }\end{array}$ & HUKUMAN \\
\hline 1 & Pasal 2 & $\begin{array}{l}\text { Perbuatan Melawan } \\
\text { hukum dan } \\
\text { memperkaya diri } \\
\text { sendiri, merugikan } \\
\text { keuangan negara }\end{array}$ & $\begin{array}{l}\text { Pidana penjara paling } \\
\text { singkat } 4 \text { tahun dan } \\
\text { paling lama } 20 \text { tahun. } \\
\text { Dan denda paling sedikit } \\
\text { Rp. } 200.000 .000,00 \text { (dua } \\
\text { ratus juta rupiah) dan } \\
\text { paling banyak Rp. } \\
1.000 .000 .000,00 \text { (satu } \\
\text { milyar rupiah) }\end{array}$ \\
\hline 2 & pasal 3 & $\begin{array}{l}\text { Menguntungkan } \\
\text { diri sendiri, } \\
\text { menyalahgunakan } \\
\text { kewnangan, } \\
\text { merugikan } \\
\text { keuangan negara }\end{array}$ & $\begin{array}{l}\text { Penjara paling singkat } 1 \\
\text { tahun dan paling lama } 20 \\
\text { tahun atau denda paling } \\
\text { sedikit } \\
\text { Rp.50.000.000.00( lima } \\
\text { puluh juta rupiah) dan } \\
\text { paling banyak } \\
\text { Rp.1.000.000.000,00(sat } \\
\text { u milyar rupiah) }\end{array}$ \\
\hline 3 & Pasal 8 & $\begin{array}{l}\text { Menggelapkan } \\
\text { uang, membantu } \\
\text { melakukan } \\
\text { perbuatan }\end{array}$ & $\begin{array}{l}\text { Pidana penjara paling } \\
\text { singkat } 3 \text { tahun dan paling } \\
\text { lam } 15 \text { tahun dan atau } \\
\text { denda paling sedikit Rp } \\
150.000 .000,00 \text { (seratus } \\
\text { lima puluh juta) dan paling } \\
\text { banyak Rp. } 750.000 .000 .00 \\
\text { (tujuh ratus lima puluh juta } \\
\text { rupiah) }\end{array}$ \\
\hline
\end{tabular}


Jurnal ESENSI HUKUM,

Vol. 2 No. 2 Bulan Desember Tahun 2020, hlm. 23-35

Tabel 2 Undang-Undang Nomor 20 Tahun 2001

Tentang Pemberantasan Tindak Pidana Korupsi 
JUrnal ESENSI HUKUM,

Vol. 2 No. 2 Bulan Desember Tahun 2020, hlm. 23-35

\begin{tabular}{|c|c|c|c|}
\hline NO & PASAL & $\begin{array}{l}\text { UNSUR-UNSUR TINDAK } \\
\text { PIDANA }\end{array}$ & HUKUMAN \\
\hline 1 & Pasal 5 & $\begin{array}{l}\text { Menjanjikan sesuatu, } \\
\text { menerima pemberian, } \\
\text { penyelenggara negara }\end{array}$ & $\begin{array}{l}\text { Penjara paling singkat } 1 \\
\text { tahun dan paling lama } 5 \\
\text { tahun atau denda paling } \\
\text { sedikit } \\
\text { Rp. } 50.000 .000 .00 \text { ( lima } \\
\text { puluh juta rupiah) dan } \\
\text { paling banyak } \\
\text { Rp. } 250.000 .000,00 \text { (dua } \\
\text { ratus lima puluh juta } \\
\text { rupiah) }\end{array}$ \\
\hline 2 & Pasal 6 & $\begin{array}{l}\text { Memberi dan menjanjikan } \\
\text { sesuatu, mempengaruhi } \\
\text { putusan hakim }\end{array}$ & $\begin{array}{l}\text { Pidana penjara paling } \\
\text { singkat } 3 \text { tahun dan } \\
\text { paling lama } 15 \text { tahun } \\
\text { dan atau denda paling } \\
\text { sedikit } \\
\text { Rp.150.000.000.00 } \\
\text { (seratus lima puluh juta } \\
\text { rupiah) dan paling } \\
\text { banyak } \\
\text { Rp.750.000.000.00 } \\
\text { (tujuh ratus lima puluh } \\
\text { juta rupiah) }\end{array}$ \\
\hline 3 & Pasal 9 & $\begin{array}{l}\text { Pegawai } \begin{array}{l}\text { negeri, } \\
\text { memalsukan } \\
\text { jabatan }\end{array} \\
\end{array}$ & $\begin{array}{l}\text { Pidana penjara paling } \\
\text { singkat } 1 \text { tahun dan } \\
\text { paling lama } 5 \text { tahun. Dan } \\
\text { denda paling sedikit } \\
\text { Rp.50.000.000,00 ( lima } \\
\text { puluh juta rupiah) dan } \\
\text { paling banyak Rp. } \\
150.000 .000 .00 \text { (seratus }\end{array}$ \\
\hline
\end{tabular}




\begin{tabular}{|c|c|c|c|}
\hline & & & lima puluh juta rupiah) \\
\hline 4 & Pasal 10 & $\begin{array}{l}\text { Menghancurkan, merusak } \\
\text { barang, pejabat yang } \\
\text { berwenang }\end{array}$ & $\begin{array}{l}\text { Pidana penjara paling } \\
\text { singkat } 2 \text { tahun dan } \\
\text { paling lama } 7 \text { tahun. Dan } \\
\text { denda paling sedikit } \\
\text { Rp.100.000.000,00 } \\
\text { seratus juta rupiah) dan } \\
\text { paling banyak Rp. } \\
350.000 .000 .00 \text { (tiga } \\
\text { ratus lima puluh juta } \\
\text { rupiah) }\end{array}$ \\
\hline 5 & Pasal 11 & $\begin{array}{l}\text { Penyelenggara negara, } \\
\text { kekuasaan dan kewenangan }\end{array}$ & $\begin{array}{l}\text { Pidana penjara paling } \\
\text { singkat } 1 \text { tahun dan } \\
\text { paling lama } 5 \text { tahun. Dan } \\
\text { denda paling sedikit } \\
\text { Rp.50.000.000,00 ( lima } \\
\text { puluh juta rupiah) dan } \\
\text { paling banyak Rp. } \\
250.000 .000 .00 \text { (dua } \\
\text { ratus lima puluh juta } \\
\text { rupiah) }\end{array}$ \\
\hline
\end{tabular}

3.3 Upaya Penanggulangan Tindak Pidana Korupsi Pada Masa Pandemi Covid19

Penanggulangan pelaku tindak pidana korupsi merupakan suatu yang berkaitan terhadap revolusi mental bagi masyarakat indonesia, hal ini bukan sekedar menangani penegakan hukum yang sifatnya refrensif dan preventif. Penanggulangannya adalah masyarakat harus menjadi suatu landasan untuk membentuk yang namanya kebijakan. Kerusakan yang diakibatkan oleh korupsi sifatnya lokal yang berdampak dirasakan oleh banyak negara maju maka bahaya yang diakibatkan oleh korupsi bersifat multidimensi. ${ }^{13}$

Berdasarkan Peraturan Pemerintah yang diatur dalam Undang-undang Nomor 1 Tahun 2020 tentang kebijakan keuangan negara dan stabilitas sistem keuangan dan penanganan pan demi corona virus disease 2019 (covid-19) dan dalam rangka untuk menghadapi ancaman yang membahayakan perekonomian nasional atau stabilitas keuangan atau sering disebut dengan Perpu 1/2000.

13 Arief,B. (2008). Beberapa Aspek Kebijakan Penegakan Hukum Dan Pengembangan Hukum Pidana. Bandung: Citra Aditya Bakti, hlm. 69 
Untuk dapat melaksanakan anggaran pendapatan dan belanja negara dalam rangka penanganan Pandemi covid-19 dan untuk mengahadap suatu ancaman yang dapat membahayakan perekonomian nasional dan stabilitas sistem keuangan. Dalam kebijakan untuk mendapatkan keuangan negara yang termasuk kebijakan keuangan negara, pemerintah dapat memberikan penanggulangan yang termasuk penanggulangan di bidang perpajakan penanggulangan belanja negara yang termasuk didalamnya penanggulangan di bidang keuangan daerah dan kebijakan pembiayaan.

Kebijakan penal bisa diartikan sebagai suatu perilaku dari semua pameran untuk menetapkan suatu perbuatan sebagai bentuk tindak pidana dengan suatu tertentu, maka dalam undang-undang dimaksud untuk menjamin kepastian hukum, menghindari penafsiran hukum dan memberikan perlindungan terhadap hak-hak sosial dan ekonomi masyarakat serta menjamin keadilaan. Pada hakikatnya sarana penal merupakan bagian dari usaha penegakan hukum oleh karena itu kebijakan penegak hukum (Law Enforcement). Penanggulangan korupsi dapat dilakukan dengan cara menyerahkan kasus tindak pidana korupsi yang terjadi kepada pihak penegak hukum dalam hal ini polisi, jaksa dan KPK untuk diproses sesuai dengan ketentuan hukum yang berlaku, dimana hukuman yang dijatuhkan kepada pelaku. Moeljatno menyatakan bahwa perbuatan itu merupakan suatu perbuatan yang dilarang dan diancam dengan pidana bagi barang siapa yang melanggar larangan tersebut. ${ }^{14}$

Penanganan tindak pidana dengan kebijakan upaya penal dengan memberikan sanksi barang siapa yang melakukan tindak pidana korupsi adalah reaksi atas perbuatan yang dilakukan, tetapi didalam proses penanggulangan tindak pidana korupsi ini menggunakan upaya penal yang sangat cenderung reaktif. Upaya dalam penanggulangan tindak pidana korupsi harus lebih menitikberatkan pada pemberantasan dan penindasan karena hakikat dari upaya penal adalah bagian dari usaha dari penegak hukum maka kebijakan hukum pidana itu bagian dari penegak hukum. Penanggulangan dalam memberantas tindak pidana korupsi yang dilakukan pada masa pandemi covid-19 melakukan dua strategi yaitu upaya preventif dan upaya represif:

1) Upaya preventif merupakan suatu pencegahan tindak pidana korupsi yang diarahkan untuk meminimalkan penyebab dan peluangnya terjadinya korupsi.

2) Upaya strategi reprensif merupakan setiap perbuatan yang diarahkan yang diindentifikasi diproses secara cepat dan tepat sehingga kepada pelakunya dapat diberikan sanksi sesuai yang ada diperaturan perudangundangan

Kebijakan non penal adalah suatu upaya penanggulangan kejahatan dengan tidak melakukan pidana memperbaiki kondisi-kondisi yang tertentu, dan didalamnya mencakup suatu kriminalisasi perbuatan tertentu yang menjadi

${ }^{14}$ Moeljono. (1987). Asas-Asas Hukum Pidana Indonesia. Jakarta: Bina Aksara, hlm. 37 
gejala sosial dalam masyarakat modren. Kebijakan non penal sangat diperlukan dalam melakukan penanggulangan korupsi yang memberikan pemahaman yang dapat menempakan jangkauan ilmu yang luas yang membatasi kaidah yang sifatnya rasional. ${ }^{15}$

Upaya yang dilakukan dalam menanggulangi kejahatan non penal sifatnya pencegahan tetapi sasaran utama adalah faktor-faktor kondusif yang menyebabkan terjadinya berpusat pada titik masalah yang secara langsung dapat menumbuhkan kejahatan. Tindak pidana korupsi yang semakin banyak maka sangat diperlukan ketegasan mengenai penanganannya, dalam hal ini sangat diperlukan tindakan preventif dan tindakan represif karena keduanya dapat menghasilkan penyelenggara negara yang bebas tipikor.

Korupsi mempunyai dampak yang sangat luas dalam proses penyelenggara dan pembangunan masyarakat korupsi dikategorikan sebagai extra ordinary crime, yang artinya bahwa korupsi mempunyai masalah lokal, fenomena nasional sangat mempengaruhi masyarakat dan ekonomi hal ini penting melakukan kerja sama antar internasional agar mencegah terjadinya korupsi, maka pendekatan komprehensif diperlukan saat ini untuk mencegah pemberantasan korupsi yang secara efektif. ${ }^{16}$ Pembentukan suatu aturan hukum dapat menentukan perbuatan yang harus dicegah didalam masyarakat. Kebijakan dalam penanggulangan tindak pidana dimasa pandemi covid-19 pada hakikatnya bagian dari integral dari perlindungan masyarakat yang berguna.

\section{Kesimpulan}

1. Peraturan Pemerintah dalam mengatasi penyebaran covid-19 bahwa di terbitkan Peraturan pemerintah No 1 tahun 2020 tentang kebijakan keuangan negara dan stabilitas sistem keuangan untuk memberikan penanganan Pandemi Covid-19

2. Dalam penanganan bencana adalah tanggung jawab dari pemerintah memberikan penanganan terhadap memberi perlindungan masyarakat dari ancaman bencana alam dan menjamin terselenggarakannya penanggulangan bencana yang terencana, terpadu, terkoordinasi dan menyeluruh.

3. Upaya hukum dalam memberantas tindak pidana korupsi yang dilakukan pada masa Pandemi covid 19 dilakukan dengan kebijakan penal dan kebijakan non penal

\footnotetext{
${ }^{15}$ Absori, (2014). Pemikiraan Hukum Dalam Konteks Pengembangan Ilmu Hukum Diindonesia, Yogyakarta; Genta Publishing, hlm. 14.

${ }^{16}$ Ali, M. (1998). Teori Dan Praktek Hukum Pidana Korupsi, Yogyakarta, hlm.33.
} 


\section{DAFTAR PUSTAKA}

\section{A. Buku}

Absori, (2017). Pemikiraan Hukum Dalam Konteks Pengembangan Ilmu Hukum di Indonesia, Yogyakarta: Genta Publishing.

Ali,M. (1998). Teori Dan Praktek Hukum Pidana Korupsi. Yogyakarta, 1998.

Arif,B. (2010). Bunga Rampai Kebijakan Hukum Pidana. Jakarta: Media Group

Arief,B. (2008). Beberapa Aspek Kebijakan Penegakan Hukum Dan Pengembangan Hukum Pidana. Bandung: Citra Aditya Bakti.

Hartanti,E. (2009). Tindak Pidana Korupsi, Jakarta: Sinar Erlangga.

Marzuki ,P.M. (2005). Penelitian Hukum, Jakarta: Prenada Media.

Moeljono. (1987). Asas-Asas Hukum Pidana Indonesia, Jakarta: Bina Aksara.

Sholihin,F. dan Yulianingsih,W. (2015). Kamus Hukum Kontemporer, Surabaya: Sinar Grafika.

Syamsuddin,A. (2011). Tindak Pidana Khusus, Jakarta: Sinar Grafika.

Waluyo,B. (1996). Penelitian Hukum dalam Praktik, Jakarta: Sinar Grafika.

Yayasan. (2007) Buku panduan umum pennggulangan bencana berbasis masyarakat, Bali.

\section{B. Peraturan Perundang-Undangan}

Undang-Undang Nomor 17 Tahun 2003 tentang Keuangan Negara

Undang-Undang Nomor 15 tahun 2004 tentang Pemeriksaan dan Tanggung Jawab Keuangan Negara

Undang-Undang Nomor 24 Tahun 2007 Tentang Penanggulangan Bencana

Undang-Undang Nomor 46 Tahun 2009 Tentang Pengadilan Tindak Pidana Korupsi

Perppu Nomor 1 Tahun 2020 Tentang Kebijakan Keuaangan Negara Dan Stabilitas Sistem Keuangan Untuk Memberikan Penanganan Pandemi Covid-19

Surat Edaran Komisi Pemberantasan Korupsi Republik Indonesia Nomor 8 Tahun 2020

\section{Internet}


Mubarok, F. KPK Petakan Titik Rawan Praktik Korupsi di Tengah Pandemi Covid-19. diakses di https://www.alinea.id/nasional/kpk-petakanrawan-praktik-korupsi-di-tengah-Pandemi-covid-19-b1ZLA9tQQ pada tanggal 12 juni 2020

http://repository.uib.ac.id/1153/6/S_1451091_chapter3.pdf, diakses pada tanggal 9 September 2020 